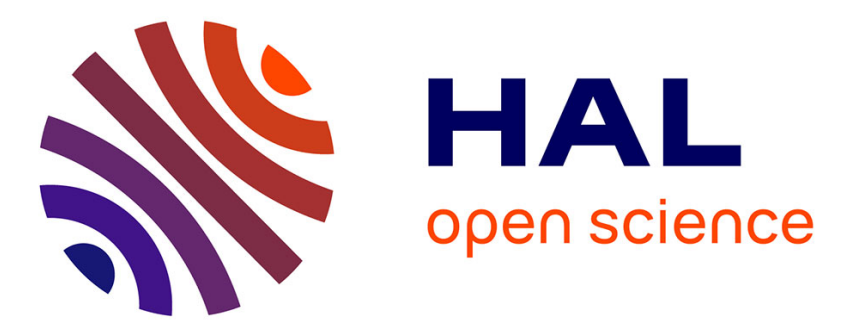

\title{
Relevance of coexpression of somatostatin and dopamine D2 receptors in pituitary adenomas
}

\author{
Alexandru Saveanu, P. Jaquet, Thierry Brue, Anne A. Barlier
}

\section{To cite this version:}

Alexandru Saveanu, P. Jaquet, Thierry Brue, Anne A. Barlier. Relevance of coexpression of somatostatin and dopamine D2 receptors in pituitary adenomas. Molecular and Cellular Endocrinology, 2008, 286 (1-2), pp.206. 10.1016/j.mce.2007.12.008 . hal-00531973

\section{HAL Id: hal-00531973 https://hal.science/hal-00531973}

Submitted on 4 Nov 2010

HAL is a multi-disciplinary open access archive for the deposit and dissemination of scientific research documents, whether they are published or not. The documents may come from teaching and research institutions in France or abroad, or from public or private research centers.
L'archive ouverte pluridisciplinaire $\mathbf{H A L}$, est destinée au dépôt et à la diffusion de documents scientifiques de niveau recherche, publiés ou non, émanant des établissements d'enseignement et de recherche français ou étrangers, des laboratoires publics ou privés. 


\section{Accepted Manuscript}

Title: Relevance of coexpression of somatostatin and dopamine $\mathrm{D} 2$ receptors in pituitary adenomas

Authors: A. Saveanu, P. Jaquet, T. Brue, A. Barlier

PII: $\quad$ S0303-7207(07)00474-1

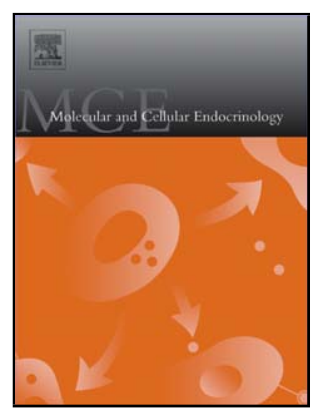

DOI: doi:10.1016/j.mce.2007.12.008

Reference: MCE 6773

To appear in: Molecular and Cellular Endocrinology

Received date:

$$
\text { 11-6-2007 }
$$

Revised date:

$10-12-2007$

Accepted date:

Please cite this article as: Saveanu, A., Jaquet, P., Brue, T., Barlier, A., Relevance of coexpression of somatostatin and dopamine D2 receptors in pituitary adenomas, Molecular and Cellular Endocrinology (2007), doi:10.1016/j.mce.2007.12.008

This is a PDF file of an unedited manuscript that has been accepted for publication. As a service to our customers we are providing this early version of the manuscript. The manuscript will undergo copyediting, typesetting, and review of the resulting proof before it is published in its final form. Please note that during the production process errors may be discovered which could affect the content, and all legal disclaimers that apply to the journal pertain. 
Relevance of coexpression of somatostatin and dopamine D2 receptors in pituitary adenomas

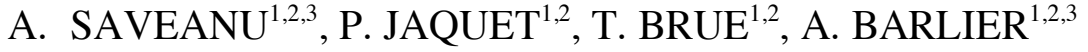

${ }^{1}$ Laboratory Interactions Cellulaires Neuroendocriniennes, UMR 6544 CNRS, Institut Fédératif Jean Roche, Faculté de Médecine Nord, Université de la Méditerranée, Marseille ${ }^{2}$ Department of Endocrinology, Centre Hospitalo-Universitaire Timone, Marseille, France. ${ }^{3}$ Laboratory of Biochemistry and Molecular Biology, Centre Hospitalo-Universitaire Conception, Marseille, France

\section{Summary}

Dopamine and somatostatin are both involved in the negative control of normal pituitary cells. Dopamine subtype 2 receptor (D2DR) and somatostatin receptor (sst) agonists, mainly directed to sst2, are used in the treatment of pituitary adenomas. Nevertheless, a majority of corticotroph and gonadotroph adenomas and a third of somatotroph adenomas are still not sufficiently controlled by these treatments. D2DR and sst1,2,3 and 5 are present in most pituitary adenomas. These receptors may interact by heterodimerization as shown for sst1sst5, sst5-D2DR, sst2-sst3 and sst2-D2DR suggesting possible additive effects. D2DR and sst 2 agonist cotreatment showed limited additivity on GH secretion in acromegaly. Moreover, new chimeric compounds with sst2, D2DR and sst5 affinity have shown an increased control of secretion and/or proliferation of different types of pituitary adenomas in cell culture. Together with the multi-sst ligand drugs recently developed, these dopamine-somatostatin ligands represent a new opportunity in the combinatory treatment of pituitary adenomas. 


\section{Introduction}

Depending of the point of view that is considered, different target audiences will find coexpression of somatostatin receptors (sst) and dopamine subtype 2 receptors (D2DR) in pituitary adenomas relevant for distinct reasons: clinicians are mainly interested in the potential therapeutic use of the cooperation of various receptor subtypes, while basic researchers are more eager to decipher the mechanisms whereby such a cooperation may occur. These are the topics that we will briefly address in the present review with reference to the most recent findings in the field.

\section{Sst and D2DR in pituitary adenomas}

Both somatostatin and dopamine are neurohormones implicated in the negative control of hormonal secretion of the anterior pituitary gland [1,2]. They act through binding to membrane receptors: G protein coupled receptors (GPCR), that are present on the cells of the normal pituitary: somatostatin receptor subtypes 1, 2, 3 and 5 [3-6] and D2DR [7]. Pituitary tumors are mostly benign tumors derived from different pituitary cell types, that retain most of the characteristics of the original cells [8]. Accordingly sst subtypes 1, 2, 3 and 5 and D2DR were found to be present in a majority of pituitary adenomas, irrespective of their type (reviewed in [9], [10]). The interstudy variability is reflecting both a different sensitivity of the techniques used and a huge heterogeneity of these adenomas. However, like others [4,1113], we found in most GH adenomas [14-16], sst2, sst5 and D2DR mRNA coexpression, in keeping with protein studies $[10,13,17,18]$ showing the same trend. Moreover half of GH tumors also disclosed sst3 and sst1 coexpression. The latter is present mainly in mixed GH and PRL adenomas [14]. Indeed, in prolactinomas, sst1, sst5, sst2 and of course D2DR are present $[3,4,10,12,18-20]$. Nonfunctioning pituitary adenomas (NFPA), that are mostly of gonadotroph origin, express sst2, sst3 [11,12,17,21,22] and D2DR [10,23], seldom associated with sst1[12]. Corticotroph adenomas mainly express sst5, sst2 [3,24] and D2DR [10,25] and less frequently sst1 and sst3 [3-5]. The least frequent pituitary adenomas, TSH adenomas, express sst1, sst2 and sst5 [4,26,27] and D2DR receptors ( [10] and personal unpublished data). Despite a great variability in the techniques from one study to another (Northern Blot, Quantitative-PCR, radioactive binding studies or immunohistochemistry), D2DR expression is overall associated with two or more sst subtypes in most tumors with some patterns : sst2+sst5 in GH adenomas, sst3+sst2 in NFPA or sst1+sst5 in prolactinomas. Such observations however did not always correlate with the efficacy of the corresponding drugs. Indeed, while D2DR agonists are efficient in treating more than $90 \%$ prolactinomas (reviewed in [28], [29]), somatostatin analogs clinically in use (Octreotide and Lanreotide) 
only control about $80 \%$ of TSHoma [30,31] and $60 \%$ of GH adenomas (reviewed in [32]). Moreover, sst or D2DR agonists control less than $20 \%$ of NFPA adenomas ( reviewed in [33]) and even fewer corticotroph adenomas [25,34,35]. This discrepancy between the "presence" of sst and D2DR receptors and the partial efficacy of agonist drugs needs to be explained.

\section{Why do current sst and D2DR agonists only partially control pituitary adenomas?}

Clinically used somatostatin analogs, octreotide and lanreotide, have sst subtype affinities, that are clearly different from those of native somatostatin (SRIF14) (see table 1). They have a good sst2 affinity, while sst5 affinity is lower than that of SRIF-14 (the ratio of sst2 and sst5 affinities being about 12 for octreotide and 18 for lanreotide). Octreotide also has some sst3 affinity; about 25 times lower than that of SRIF14. Both drugs do not recognize sst1 and sst4 subtypes. Sst4 is not or is weakly expressed in pituitary and the functions of sst3 in pituitary remains unclear. However, sst5 subtype could be an important actor in suppressing GH, ACTH and PRL secretion from human pituitary adenomas [19,24,36], while sst1 subtype also may suppress the secretion or the viability of $\mathrm{GH}$, prolactin and gonadotroph adenoma cells in vitro $[22,37,38]$. So, octreotide and lanreotide do not cover all the sst subtypes able to suppress secretion and proliferation of different pituitary adenoma cell types.

Furthermore, the level of expression of sst subtypes and D2DR is an important factor of agonist action. According to our experiments in GH tumors [39], as measured by real-time quantitative PCR, sst 2 mRNA ranged from 0.01 to 3 copy sst $2 /$ copy $\beta$ Gus. Other recent studies using this technique found a similarly wide range of mRNA expression [12]. Such a wide range of sst2 expression levels explains, at least partially, the variability of $\mathrm{GH}$ suppression by octreotide and lanreotide in acromegalic patients. Indeed, the in vitro or in vivo octreotide sensibility is correlated with sst2 mRNA levels in somatotroph tumors [14,40,41]. Similarly, D2DR quantitative detection showed a wide range of D2DR mRNA amounts, ranging from 0.01 to 15 copy/copy $\beta$ gus [15] and GH or PRL suppression under D2DR agonists was correlated to D2DR levels in lactotroph and somatotroph tumors in vitro [15,42]. In gonadotrophinomas, octreotide was found to be less efficacious than in somatotroph adenomas, probably also because sst 2 mRNA expression is 20 times lower than in GH tumors $([21,40])$. However, the efficacy of octreotide is not always $100 \%$ correlated to the sst2 expression level. Other mechanisms can be involved in drug resistance, like defects downstream of the receptors. This was clearly shown for D2DR in resistant prolactinomas [42-44]. 


\section{Hopes for new treatments}

Thus, if the expression amount of target receptors is a crucial parameter for the response level to specific agonists (sst2 for octreotide and D2DR for cabergoline), how could this limitation be overcome?

The simplest solution is to simultaneously activate several types of inhibitory receptors in order to obtain an additive effect on secretion and proliferation. Clinicians had already tried empirically this option, in somatotroph adenomas (reviewed in [45]) or in NFPA [46] by coadministration of the available sst2 (octreotide/lanreotide) and D2DR analogs (bromocriptine, cabergoline, quinagolide). Most of these studies showed some additivity between both drugs but the overall results were modest. For example, in one of the latest and most optimistic studies in acromegaly, co-administration of cabergoline and somatostatin analogs slightly improved the control of GH secretion from mean GH values of 6.6 to an average of $4.6 \mathrm{ng} / \mathrm{ml}$ [47].

Two kinds of in vitro experiments have successively raised new hopes:

The first one concerns a new actor: sst5. This sst subtype is present in most GH, PRL and ACTH tumors. Drugs with selective affinity for sst5 were able to suppress GH and ACTH secretion from human pituitary adenomas in vitro [24,36]. Moreover, the combination of sst5 specific drugs with sst2 specific agonists showed an improvement of GH suppression in about half of investigated GH tumors [14,36].

The second hope is related to the demonstration of GPCR oligomerization (reviewed in [48-50]). In some cases, the heterodimerization of two GPCR induces a modification of the ligand binding and a synergy in receptor activation as elegantly illustrated for sst5 and D2DR by Patel's group [51] in transfected heterologous cells. The D2DR-sst5 dimer was characterized by a greater affinity for both D2DR and sst agonists, and presented an enhanced coupling with adenylyl cyclase [51].

Most studies on new somatostatin and somatostatin-dopamine analogs were the consequence of these two demonstrations: sst5 mediated hormone suppression and cooperation between ssts and D2DR in suppressing hormones or cell proliferation of pituitary adenomas.

Therefore, two types of ligands have been synthesized for the treatment of pituitary adenomas: the multiple-sst ligands and the sst-D2DR chimeric drugs. The former are closer to native somatostatin, since they have both sst2 and sst5 affinity: BIM-23244 [40], or sst5+sst2+sst3+sst1 affinity, as SOM-230 [52] and others: PTR3173 [53], KE108 [54], BIM- 
23A779 [15]. The latter are represented by the so-called «dopastatin » drugs like BIM23A387, associating sst2 and D2DR affinity, or BIM-23A760/761, which recognize sst2, D2DR and sst5 (see below).

\section{Dimerization of sst and D2DR}

GPCR dimerization is implicated in several phenomena, such as receptor trafficking (membrane expression and internalization), ligand binding and $\mathrm{G}$ protein signaling. Sst and D2DR receptors were among the first receptors for which homo- and heterodimerization was demonstrated.

Constitutive homodimerization of sst5 [55,56]. and D2DR[57,58] is enhanced by specific agonists. Sst1 is the only subtype that was present in a monomeric state under basal or stimulated conditions, when expressed alone [51,55]. On the contrary, sst 2 was present as constitutive dimers at cell surface and the dimers were dissociated by application of the agonist [59]. In conclusion, sst2, sst5 and D2R were all present as constitutive and/or ligand induced homodimers when expressed alone. However, these studies were performed in transfected models where a single receptor was expressed, that represent neither a physiological state, nor the situation of pituitary tumors.

Heterodimerization of GPCR has been described for an increasing number of GPCR couples and opens new avenues in physiology, physiopathology and pharmacology ([48-50] for review). For example, heterodimerization of angiotensin AT1R and bradikinin B2 receptors was involved in eclampsia [60] and the beta2 adrenergic receptors and EP1R (PGE2 receptor) heterodimerization allowed a functional antagonism in the airway smooth muscle with consequences in asthma treatment [61]. Furthermore, new drugs have been designed and synthesized in order to specifically target receptor heterodimers, as for example delta-kappa opioid heterodimers in the spinal cord [62]. The D2DR-sst5 heterodimerization is associated with a modification of the ligand binding and a synergistic effect on the activation of transduction pathway [51] (table 1). The recent described D2DR and sst2 heterodimerization was also associated with a reciprocal modification of ligand binding, improved EC50 in cAMP inhibition and increased internalization for sst2 [63] (table 1). Sst1 and sst5 also form heterodimers with a crossover activation [56], while sst2 and sst3 heterodimers are characterized by a predominance of sst 2 signaling associated with sst3 silencing [64]. Overall, sst5, sst2, sst1, sst3 and D2DR are able to form heterodimers in various combinations that sometimes drastically modifies their function. However, in prolactinomas where sst5 and D2DR are co-expressed, we only demonstrated a slight 
additivity of sst5 and D2DR specific agonists in cell culture [19]. This modest additive effect was clearly different from the strong synergistic effect induced by sst5-D2DR heterodimerization observed in cotransfected $\mathrm{CHO}$ cells [51]. Reciprocal interaction of sst5 and D2DR is complex, as one paper [65] suggested that the presence of D2DR in specific GH adenoma types is associated with lesser efficacy of sst5 agonists on GH suppression. Moreover, the heterodimerization pattern of D2DR and sst2 was clearly different in $\mathrm{CHO} / \mathrm{HEK} 293$ cells and rat striatal neurons[63] . In these neurons, naturally coexpressing sst2 and D2DR, constitutive sst2-D2DR heterodimers are present and heterodimerization is further promoted only by dopamine [63] . Thus, experimental results obtained in transfected cell lines, clearly need to be validated in the specific context of pituitary cells.

\section{Sst and D2DR chimeric compounds}

In order to simultaneously target sst and D2DR, chimeric molecules associating structural parts of somatostatin (sst agonist) and dopamine (D2DR agonist) were synthesized. They define a new class of drugs, the so-called "dopastatins" [39].

The first molecule of this class, BIM-23A387 is characterized by an excellent sst2 affinity higher than that of native somatostatin, and a good D2DR affinity (see table 2). For somatotroph adenomas partially responders to octreotide, this drug appears to be more efficacious than octreotide in suppressing GH secretion in vitro [16,66]. In addition the sst2/D2DR chimera suppressed GH and PRL secretion at 50 times lower concentrations than a combination of selective sst2 and D2DR drugs [16]. That was a clear demonstration allowing to expect a better result of this chimeric molecule than the co-administration of currently available, octreotide and cabergoline in the treatment of pituitary adenomas. Both sst2 and D2DR antagonists were necessary to completely reverse the GH suppression induced by the sst2/D2DR chimera, demonstrating implication of both sst and D2DR moieties in GH suppression [16]. Moreover, the sst2/D2DR chimera was significantly more potent than the multi-sst ligand, BIM-23244 to suppress the GH secretion in cell culture of most analyzed GH adenomas [39]. However, in 10 non-functioning pituitary adenomas, the chimeric sst2/D2DR molecule appeared as potent as bromocriptine in decreasing cell viability [67], while in another cellular context, BIM-23A387 seemed more potent than individual sst and D2DR compounds in suppressing the growth of lung carcinoma cells [68].

The sst5 affinity of the multi-sst ligands like SOM-230 is important for GH, PRL and ACTH suppression by this drug [69,70]. Consequently, the association of an sst5 affinity to the sst2/D2DR chimeric compound seemed a good option. Among several dopastatins 
presenting with variable sst2, sst5 and D2DR affinities (table 2), the best GH suppressing drugs in cell culture were BIM-23A760 and BIM-23A761 [39]. These sst2/sst5/D2DR agonists presented a strong sst2 affinity, higher than that of the sst2/D2DR chimera or native somatostatin, and a D2DR affinity roughly similar to that of the sst2/D2DR chimera (see table 1). Sst5 affinity was moderate and variable: BIM-23A760 and BIM-23A761 presented an sst5 affinity two fold higher than that of octreotide. Recently, the involvement of sst5 affinity of BIM-23A761 in suppressing cell proliferation was demonstrated in one GH adenoma in vitro [71]. In cultured lymphocytes, the importance of the sst5 affinity was pointed out : the sst2/sst5/D2DR chimera suppressed the mitogen-activated proliferation by inhibiting cell progression into the $\mathrm{S}$ and the $\mathrm{G} 2 / \mathrm{M}$ phase, while an sst2/D2DR chimera inhibited bromodeoxyuridine incorporation only during the $S$ phase [72]. In our experience, the sst2/sst5/D2DR dopastatins were more potent than the sst2/D2DR dopastatin [39] and than the multi-sst ligands, BIM-23A779 or SOM-230 [73] in suppressing GH and PRL secretion from $\mathrm{GH}$ adenomas in vitro. In other types of tumors, BIM-23A760 appeared at least as potent as cabergoline to suppress PRL secretion of prolactinomas in vitro [74], and showed antiproliferative effects in about half of nonfunctioning pituitary adenomas in cell culture $[75]$.

These data suggest that dopastatins may represent a new therapeutic approach in acromegaly, as well as in other types of pituitary tumors. Moreover, other tumors coexpressing sst and D2DR receptors, as gastrointestinal endocrine tumors [76] where tachyphylaxis limits somatostatin analogs efficacy, could also represent a target of dopastatins.

\section{How do the ssts and D2R cooperate?}

As already shown, D2DR cooperate with either sst2 and sst5 through heterodimerization. Sst2 is the pivotal sst subtype in most human tumors [13,17], the principal mediator of current sst analogs action (octreotide and lanreotide) and the main sst subtype in the setting of somatostatin receptor scintigraphy [77]. Sst2 was known to form heterodimers with sst3 and $\mathrm{Mu}$ opioid receptors [64,78]. Its recently demonstrated heterodimerization with D2DR [63], offer a support for the functional cooperation showed by the chimeric sst2- D2DR drugs in pituitary adenomas. A striking feature of the demonstrated sst2-D2DR heterodimerization is the EC50 amelioration in cAMP inhibition, by somatostatin and quinpirole (D2DR agonist) coincubation [63].

Further, other experimental evidences suggest that in membrane organization, in 
specialized microdomains, certain GPCR, G proteins and their effectors are organized together (reviewed in $[79,80]$ ). The efficiency and specificity of signal transduction could be dictated by the stoichiometry of transducer elements in these microdomains, as demonstrated for Gs coupled receptors [81]. Several G proteins are shared by ssts and D2DR. Consequently, chimeric sst/D2R ligands may trigger transduction pathways different from those triggered by specific sst2 and D2DR agonists. Indeed, in rat striatal neurons, sst2-D2DR heterodimers are already assembled at the cell surface and further dimerization is promoted by dopamine, but not by either somatostatin or quinpirole [63] .

To date, sst2 were not found to exhibit any heterodimerization with sst5. The group that demonstrated D2DR-sst5, D2DR-sst2 and sst1-sst5 heterodimerization does not mention the possibility of heterodimerization of sst2 with either sst1 or sst5 [59]. The mechanisms whereby sst2 cooperate with sst5 seem different. Recently, another group underlined the difference between sst 2 and sst5 subcellular localization in transfected $\mathrm{CHO}$ and mouse AtT20 cell lines, in basal and stimulated conditions [82]. They suggested that the different localizations could explain the lack of sst2-sst5 direct heterodimerization. In the same study an indirect interaction between sst 2 and sst5 was clearly demonstrated while sst5 cotransfection and co-stimulation modified sst2 internalization. The internalization of sst2 is also promoted by D2DR activation, with internalized vesicles expressing both sst2-D2DR and only one receptor, witnessing for a complex phenomenon[63].

Pharmacological concepts support other hypothesis for sst2-sst5 and sst2-D2DR cooperation without the necessity of heterodimerization $[79,80,83]$. As sst2, sst5 and D2DR showed each one the capacity to heterodimerize with other receptors $[78,84]$ and pituitary cells express concomitantly more than 70 different GPCR [85], it is possible that one or more other GPCRs represent the « missing link » accounting for sst2, sst5 and D2DR cooperation. Other receptors, like EGF receptors, are physically and functionally interacting with ssts [86] and may also be involved in sst-D2DR cellular interactions.

The concept of agonist-selective trafficking of receptor signaling [87] underlines that any agonist action is different and context dependent. Different drugs can change the quality as well as the quantity of the signal from one receptor, even when these drugs are considered as full agonists in a given cell condition. Indeed, agonists of equivalent affinity may stabilize different conformations of the same receptor and selectively activate one or another subtype of $G$ protein [79]. In our experience of multi-sst ligands or sst-D2DR chimeras, drugs with similar receptor affinity, shown as full agonists in one-pathway in vitro functional assay, had a different efficacy in GH suppression of pituitary adenoma cells [15]. 
Another aspect supporting the better efficacy of the chimeric drugs is the half life of the drug. Indeed, one clear advantage of octreotide, when this drug was developed, was that its plasma half life was of 1.5 hours in comparison to only a few minutes for SRIF14 (reviewed in [88]). The efficacious multi-sst ligand pasireotide (SOM-230) presents an even longer half-life [52,89]. One dopastatin, BIM-23A760, was also shown to have a prolonged effect on GH suppression in vitro [73] and in vivo in an animal model [90].

In conclusion, functional D2DR and multiple sst subtypes are present in pituitary adenomas and they can cooperate in order to suppress hormone secretion and cell proliferation. This cooperation is further increased by the chimeric sst-D2DR drugs. More data on cell proliferation, specificity and safety profiles of these complex chimeric sst-D2DR drugs will be necessary in the years to come in order to validate a possible clinical use. The characterization of the interactions triggered at membrane level and in the transduction pathways represents another challenge. If "dopastatins" may become relevant for the future therapeutics of pituitary adenoma, they already allowed and will further broaden our understanding of D2DR and sst actions and interactions.

Acknowledgments: This work was supported by Ipsen-Biomeasure, inc. (Milford, MA), by Centre National de la Recherche Scientifique, by the Association pour le Développement des Recherches Médicales au Centre Hospitalier Régional de Marseille (ADEREM) and by a grant from Novartis France. 
Table 1:

Modifications induced by D2DR heterodimerization with sst5 (left column) and sst2 (right column) in cotransfected heterologous cells (CHO and/or HEK293).

\begin{tabular}{|l|l|l|}
\hline & Sst5-D2DR & Sst2-D2DR \\
\hline $\begin{array}{l}\text { Ligand induced } \\
\text { heterodimerization }\end{array}$ & $\begin{array}{l}\text { YES } \\
\text { Sst5 agonist }+ \text { D2DR agonist } \geq \\
\geq \text { sst5 agonist } \geq \\
\geq \text { D2DR agonist }\end{array}$ & $\begin{array}{l}\text { YES } \\
\text { Sst2 agonist + D2DR agonist }= \\
\text { = D2DR agonist }> \\
>\text { Sst2 agonist }\end{array}$ \\
\hline Ligand binding & $\begin{array}{l}\text { D2DR agonist } \uparrow \\
\text { Sst5 agonist } \uparrow \uparrow\end{array}$ & $\begin{array}{l}\text { D2DR agonist } \uparrow \\
\text { Sst2 agonist }=\text { ( total number of } \\
\text { binding sites } \uparrow \text { ) }\end{array}$ \\
\hline $\begin{array}{l}\text { Activation of } \\
\text { transduction } \\
\text { pathway (cAMP) }\end{array}$ & $\begin{array}{l}\text { Sst5+D2DR agonist }> \\
>\text { sst5 agonist }= \\
=\text { D2DR agonist }\end{array}$ & $\begin{array}{l}\text { Sst2+D2DR agonist }> \\
>\text { D2DR agonist (EC50) }\end{array}$ \\
\hline $\begin{array}{l}\text { Receptor } \\
\text { internalization }\end{array}$ & ND & $\begin{array}{l}\text { Sst2 agonist } \neq \\
\text { Sst2 } \uparrow \text { (prolonged) }\end{array}$ \\
\hline
\end{tabular}

Data summarized from Rocheville et al. [51] and Baragli et al. [63]

$\uparrow$ increased, $\uparrow \uparrow$ sharply increased, $=$ similar,

$\neq$ modified (decreased as compared to sst 2 expressing only cells, but earlier action )

In experiments: Sst5 agonist $=$ somatostatin 14; Sst 2 agonist $=$ somatostatine 14; D2DR agonist $=$ dopamine or quinpirole. $\mathrm{ND}=$ not done 
Table 2 :

Human sst and D2DR binding affinities of chimeric dopastatin drugs as compared to native somatostatin, commonly used somatostatin drugs and multi-sst ligands (nmol/L).

\begin{tabular}{|c|c|c|c|c|c|c|}
\hline Compound & sst 1 & sst2 & sst3 & sst4 & sst5 & D2DR \\
\hline SRIF $14^{4}$ & 2.3 & 0.2 & 1.4 & 1.8 & 1.4 & ND \\
\hline \multicolumn{7}{|c|}{ Sst2 preferential agonists } \\
\hline Octreotide $^{1}$ & 1140 & 0.6 & 34 & 7030 & 7.0 & ND \\
\hline Lanreotide $^{1}$ & 2129 & 0.7 & 98 & 1826 & 12.7 & ND \\
\hline \multicolumn{7}{|c|}{ Multi-sst ligands } \\
\hline BIM-23244 ${ }^{1}$ & $>1000$ & 0.3 & 133 & $>1000$ & 0.7 & ND \\
\hline SOM- $230^{2}$ & 9.3 & 1.0 & 1.5 & $>100$ & 0.2 & ND \\
\hline BIM-23A77933 & 2.5 & 0.3 & 0.6 & 20 & 0.6 & ND \\
\hline \multicolumn{7}{|l|}{ Dopastatins } \\
\hline BIM-23A387 & 293 & 0.2 & 77 & $>1000$ & 26 & 22 \\
\hline BIM-23A758 & 468 & 0.1 & 324 & $>1000$ & 27 & 13 \\
\hline BIM-23760 & 622 & 0.03 & 160 & $>1000$ & 3.1 & 15 \\
\hline BIM-23761 & 462 & 0.06 & 52 & $>1000$ & 3.7 & 27 \\
\hline BIM-23765 & $>1000$ & 0.2 & 76 & $>1000$ & 7 & 9 \\
\hline
\end{tabular}

Data for SOM-230 are from Weckbecker et al. [39]. The values for the BIM compounds are from Ipsen as previously published 1 [40] , 2 [52] and 4 [15]. ND=not done.

References:

Bibliography

[1] Guillemin, R. (2005) Hypothalamic hormones a.k.a. hypothalamic releasing factors. J Endocrinol 184, 11-28.

[2] Ben-Jonathan, N. and Hnasko, R. (2001) Dopamine as a prolactin (PRL) inhibitor. Endocr Rev 22, 724-63.

[3] Miller, G.M., Alexander, J.M., Bikkal, H.A., Katznelson, L., Zervas, N.T. and Klibanski, A. (1995) Somatostatin receptor subtype gene expression in pituitary adenomas. J Clin Endocrinol Metab 80, 1386-92.

[4] Panetta, R. and Patel, Y.C. (1995) Expression of mRNA for all five human somatostatin receptors (hSSTR1-5) in pituitary tumors. Life Sci 56, 333-42. 
[5] Batista, D.L., Zhang, X., Gejman, R., Ansell, P.J., Zhou, Y., Johnson, S.A., Swearingen, B., Hedley-Whyte, E.T., Stratakis, C.A. and Klibanski, A. (2006) The effects of SOM230 on cell proliferation and adrenocorticotropin secretion in human corticotroph pituitary adenomas. J Clin Endocrinol Metab 91, 4482-8.

[6] Thoss, V.S., Perez, J., Probst, A. and Hoyer, D. (1996) Expression of five somatostatin receptor mRNAs in the human brain and pituitary. Naunyn Schmiedebergs Arch Pharmacol 354, 411-9.

[7] Mansour, A., Meador-Woodruff, J.H., Bunzow, J.R., Civelli, O., Akil, H. and Watson, S.J. (1990) Localization of dopamine D2 receptor mRNA and D1 and D2 receptor binding in the rat brain and pituitary: an in situ hybridization-receptor autoradiographic analysis. J Neurosci 10, 2587-600.

[8] Asa, S.L. and Ezzat, S. (1998) The cytogenesis and pathogenesis of pituitary adenomas. Endocr Rev 19, 798-827.

[9] Moller, L.N., Stidsen, C.E., Hartmann, B. and Holst, J.J. (2003) Somatostatin receptors. Biochim Biophys Acta 1616, 1-84.

[10] Stefaneanu, L., Kovacs, K., Horvath, E., Buchfelder, M., Fahlbusch, R. and Lancranjan, L. (2001) Dopamine D2 receptor gene expression in human adenohypophysial adenomas. Endocrine 14, 329-36.

[11] Nielsen, S., Mellemkjaer, S., Rasmussen, L.M., Ledet, T., Astrup, J., Weeke, J. and Jorgensen, J.O. (1998) Gene transcription of receptors for growth hormone-releasing peptide and somatostatin in human pituitary adenomas. J Clin Endocrinol Metab 83, 2997-3000.

[12] Taboada, G.F., Luque, R.M., Bastos, W., Guimaraes, R.F., Marcondes, J.B., Chimelli, L.M., Fontes, R., Mata, P.J., Filho, P.N., Carvalho, D.P., Kineman, R.D. and Gadelha, M.R. (2007) Quantitative analysis of somatostatin receptor subtype (SSTR1-5) gene expression levels in somatotropinomas and non-functioning pituitary adenomas. Eur $\mathrm{J}$ Endocrinol 156, 65-74.

[13] Schaer, J.C., Waser, B., Mengod, G. and Reubi, J.C. (1997) Somatostatin receptor subtypes sst1, sst2, sst3 and sst5 expression in human pituitary, gastroenteropancreatic and mammary tumors: comparison of mRNA analysis with receptor autoradiography. Int J Cancer 70, 530-7.

[14] Jaquet, P., Saveanu, A., Gunz, G., Fina, F., Zamora, A.J., Grino, M., Culler, M.D., Moreau, J.P., Enjalbert, A. and Ouafik, L.H. (2000) Human somatostatin receptor subtypes in acromegaly: distinct patterns of messenger ribonucleic acid expression and hormone suppression identify different tumoral phenotypes. J Clin Endocrinol Metab $85,781-92$.

[15] Saveanu, A., Gunz, G., Guillen, S., Dufour, H., Culler, M.D. and Jaquet, P. (2006) Somatostatin and dopamine-somatostatin multiple ligands directed towards somatostatin and dopamine receptors in pituitary adenomas. Neuroendocrinology 83, 258-63.

[16] Saveanu, A., Lavaque, E., Gunz, G., Barlier, A., Kim, S., Taylor, J.E., Culler, M.D., Enjalbert, A. and Jaquet, P. (2002) Demonstration of enhanced potency of a chimeric somatostatin-dopamine molecule, BIM-23A387, in suppressing growth hormone and prolactin secretion from human pituitary somatotroph adenoma cells. J Clin Endocrinol Metab 87, 5545-52.

[17] Reubi, J.C., Waser, B., Schaer, J.C. and Laissue, J.A. (2001) Somatostatin receptor sst1-sst5 expression in normal and neoplastic human tissues using receptor autoradiography with subtype-selective ligands. Eur J Nucl Med 28, 836-46.

[18] Thodou, E., Kontogeorgos, G., Theodossiou, D. and Pateraki, M. (2006) Mapping of somatostatin receptor types in GH or/and PRL producing pituitary adenomas. J Clin 
Pathol 59, 274-9.

[19] Jaquet, P., Ouafik, L., Saveanu, A., Gunz, G., Fina, F., Dufour, H., Culler, M.D., Moreau, J.P. and Enjalbert, A. (1999) Quantitative and functional expression of somatostatin receptor subtypes in human prolactinomas. J Clin Endocrinol Metab 84, 3268-76.

[20] Caccavelli, L., Feron, F., Morange, I., Rouer, E., Benarous, R., Dewailly, D., Jaquet, P., Kordon, C. and Enjalbert, A. (1994) Decreased expression of the two D2 dopamine receptor isoforms in bromocriptine-resistant prolactinomas. Neuroendocrinology 60, 314-22.

[21] Saveanu, A., Morange-Ramos, I., Gunz, G., Dufour, H., Enjalbert, A. and Jaquet, P. (2001) A luteinizing hormone-, alpha-subunit- and prolactin-secreting pituitary adenoma responsive to somatostatin analogs: in vivo and in vitro studies. Eur $\mathbf{J}$ Endocrinol 145, 35-41.

[22] Zatelli, M.C., Piccin, D., Bottoni, A., Ambrosio, M.R., Margutti, A., Padovani, R., Scanarini, M., Taylor, J.E., Culler, M.D., Cavazzini, L. and degli Uberti, E.C. (2004) Evidence for differential effects of selective somatostatin receptor subtype agonists on alpha-subunit and chromogranin a secretion and on cell viability in human nonfunctioning pituitary adenomas in vitro. J Clin Endocrinol Metab 89, 5181-8.

[23] Pivonello, R., Matrone, C., Filippella, M., Cavallo, L.M., Di Somma, C., Cappabianca, P., Colao, A., Annunziato, L. and Lombardi, G. (2004) Dopamine receptor expression and function in clinically nonfunctioning pituitary tumors: comparison with the effectiveness of cabergoline treatment. J Clin Endocrinol Metab 89, 1674-83.

[24] van der Hoek, J., Waaijers, M., van Koetsveld, P.M., Sprij-Mooij, D., Feelders, R.A., Schmid, H.A., Schoeffter, P., Hoyer, D., Cervia, D., Taylor, J.E., Culler, M.D., Lamberts, S.W. and Hofland, L.J. (2005) Distinct functional properties of native somatostatin receptor subtype 5 compared with subtype 2 in the regulation of ACTH release by corticotroph tumor cells. Am J Physiol Endocrinol Metab 289, E278-87.

[25] Pivonello, R., Ferone, D., de Herder, W.W., Kros, J.M., De Caro, M.L., Arvigo, M., Annunziato, L., Lombardi, G., Colao, A., Hofland, L.J. and Lamberts, S.W. (2004) Dopamine receptor expression and function in corticotroph pituitary tumors. J Clin Endocrinol Metab 89, 2452-62.

[26] Murabe, H., Shimatsu, A., Ihara, C., Mizuta, H., Nakamura, Y., Nagata, I., Kikuchi, H. and Nakao, K. (1996) Expression of somatostatin receptor (SSTR) subtypes in pituitary adenomas: quantitative analysis of SSTR2 mRNA by reverse transcriptionpolymerase chain reaction. J Neuroendocrinol 8, 605-10.

[27] Yoshihara, A., Isozaki, O., Hizuka, N., Nozoe, Y., Harada, C., Ono, M., Kawamata, T., Kubo, O., Hori, T. and Takano, K. (2007) Expression of Type 5 Somatostatin Receptor in TSH-secreting Pituitary Adenomas: A Possible Marker for Predicting Long-term Response to Octreotide Therapy. Endocr J 54, 133-8.

[28] Molitch, M.E. (2005) Pharmacologic resistance in prolactinoma patients. Pituitary 8, 43-52.

[29] Colao, A., Di Sarno, A., Guerra, E., De Leo, M., Mentone, A. and Lombardi, G. (2006) Drug insight: Cabergoline and bromocriptine in the treatment of hyperprolactinemia in men and women. Nat Clin Pract Endocrinol Metab 2, 200-10.

[30] Socin, H.V., Chanson, P., Delemer, B., Tabarin, A., Rohmer, V., Mockel, J., Stevenaert, A. and Beckers, A. (2003) The changing spectrum of TSH-secreting pituitary adenomas: diagnosis and management in 43 patients. Eur J Endocrinol 148, 433-42.

[31] Caron, P., Arlot, S., Bauters, C., Chanson, P., Kuhn, J.M., Pugeat, M., Marechaud, R., Teutsch, C., Vidal, E. and Sassano, P. (2001) Efficacy of the long-acting octreotide 
formulation (octreotide-LAR) in patients with thyrotropin-secreting pituitary adenomas. J Clin Endocrinol Metab 86, 2849-53.

[32] Freda, P.U. (2002) Somatostatin analogs in acromegaly. J Clin Endocrinol Metab 87, 3013-8.

[33] Chanson, P. and Brochier, S. (2005) Non-functioning pituitary adenomas. J Endocrinol Invest 28, 93-9.

[34] Lamberts, S.W., Uitterlinden, P. and Klijn, J.M. (1989) The effect of the long-acting somatostatin analogue SMS 201-995 on ACTH secretion in Nelson's syndrome and Cushing's disease. Acta Endocrinol (Copenh) 120, 760-6.

[35] Stalla, G.K., Brockmeier, S.J., Renner, U., Newton, C., Buchfelder, M., Stalla, J. and Muller, O.A. (1994) Octreotide exerts different effects in vivo and in vitro in Cushing's disease. Eur J Endocrinol 130, 125-31.

[36] Shimon, I., Yan, X., Taylor, J.E., Weiss, M.H., Culler, M.D. and Melmed, S. (1997) Somatostatin receptor (SSTR) subtype-selective analogues differentially suppress in vitro growth hormone and prolactin in human pituitary adenomas. Novel potential therapy for functional pituitary tumors. J Clin Invest 100, 2386-92.

[37] Zatelli, M.C., Piccin, D., Tagliati, F., Ambrosio, M.R., Margutti, A., Padovani, R., Scanarini, M., Culler, M.D. and degli Uberti, E.C. (2003) Somatostatin receptor subtype 1 selective activation in human growth hormone (GH)- and prolactin (PRL)secreting pituitary adenomas: effects on cell viability, GH, and PRL secretion. J Clin Endocrinol Metab 88, 2797-802.

[38] Matrone, C., Pivonello, R., Colao, A., Cappabianca, P., Cavallo, L.M., Del Basso De Caro, M.L., Taylor, J.E., Culler, M.D., Lombardi, G., Di Renzo, G.F. and Annunziato, L. (2004) Expression and function of somatostatin receptor subtype 1 in human growth hormone secreting pituitary tumors deriving from patients partially responsive or resistant to long-term treatment with somatostatin analogs. Neuroendocrinology 79, $142-8$.

[39] Jaquet, P., Gunz, G., Saveanu, A., Dufour, H., Taylor, J., Dong, J., Kim, S., Moreau, J.P., Enjalbert, A. and Culler, M.D. (2005) Efficacy of chimeric molecules directed towards multiple somatostatin and dopamine receptors on inhibition of $\mathrm{GH}$ and prolactin secretion from GH-secreting pituitary adenomas classified as partially responsive to somatostatin analog therapy. Eur J Endocrinol 153, 135-41.

[40] Saveanu, A., Gunz, G., Dufour, H., Caron, P., Fina, F., Ouafik, L., Culler, M.D., Moreau, J.P., Enjalbert, A. and Jaquet, P. (2001) Bim-23244, a somatostatin receptor subtype 2- and 5-selective analog with enhanced efficacy in suppressing growth hormone $(\mathrm{GH})$ from octreotide-resistant human GH-secreting adenomas. J Clin Endocrinol Metab 86, 140-5.

[41] Barlier, A., Pellegrini-Bouiller, I., Gunz, G., Zamora, A.J., Jaquet, P. and Enjalbert, A. (1999) Impact of gsp oncogene on the expression of genes coding for Gsalpha, Pit-1, Gi2alpha, and somatostatin receptor 2 in human somatotroph adenomas: involvement in octreotide sensitivity. J Clin Endocrinol Metab 84, 2759-65.

[42] Pellegrini, I., Rasolonjanahary, R., Gunz, G., Bertrand, P., Delivet, S., Jedynak, C.P., Kordon, C., Peillon, F., Jaquet, P. and Enjalbert, A. (1989) Resistance to bromocriptine in prolactinomas. J Clin Endocrinol Metab 69, 500-9.

[43] Caccavelli, L., Morange-Ramos, I., Kordon, C., Jaquet, P. and Enjalbert, A. (1996) Alteration of $\mathrm{G}$ alpha subunits mRNA levels in bromocriptine resistant prolactinomas. J Neuroendocrinol 8, 737-46.

[44] Barlier, A., Pellegrini-Bouiller, I., Caccavelli, L., Gunz, G., Morange-Ramos, I., Jaquet, P. and Enjalbert, A. (1997) Abnormal transduction mechanisms in pituitary adenomas. Horm Res 47, 227-34. 
[45] Colao, A., Filippella, M., Pivonello, R., Di Somma, C., Faggiano, A. and Lombardi, G. (2007) Combined therapy of somatostatin analogues and dopamine agonists in the treatment of pituitary tumours. Eur J Endocrinol 156, S57-S63.

[46] Andersen, M., Bjerre, P., Schroder, H.D., Edal, A., Hoilund-Carlsen, P.F., Pedersen, P.H. and Hagen, C. (2001) In vivo secretory potential and the effect of combination therapy with octreotide and cabergoline in patients with clinically non-functioning pituitary adenomas. Clin Endocrinol (Oxf) 54, 23-30.

[47] Cozzi, R., Attanasio, R., Lodrini, S. and Lasio, G. (2004) Cabergoline addition to depot somatostatin analogues in resistant acromegalic patients: efficacy and lack of predictive value of prolactin status. Clin Endocrinol (Oxf) 61, 209-15.

[48] Bulenger, S., Marullo, S. and Bouvier, M. (2005) Emerging role of homo- and heterodimerization in G-protein-coupled receptor biosynthesis and maturation. Trends Pharmacol Sci 26, 131-7.

[49] George, S.R., O'Dowd, B.F. and Lee, S.P. (2002) G-protein-coupled receptor oligomerization and its potential for drug discovery. Nat Rev Drug Discov 1, 808-20.

[50] Terrillon, S. and Bouvier, M. (2004) Roles of G-protein-coupled receptor dimerization. EMBO Rep 5, 30-4.

[51] Rocheville, M., Lange, D.C., Kumar, U., Patel, S.C., Patel, R.C. and Patel, Y.C. (2000) Receptors for dopamine and somatostatin: formation of hetero-oligomers with enhanced functional activity. Science 288, 154-7.

[52] Weckbecker, G., Briner, U., Lewis, I. and Bruns, C. (2002) SOM230: a new somatostatin peptidomimetic with potent inhibitory effects on the growth hormone/insulin-like growth factor-I axis in rats, primates, and dogs. Endocrinology 143, 4123-30.

[53] Shimon, I., Rubinek, T., Hadani, M. and Alhadef, N. (2004) PTR-3173 (somatoprim), a novel somatostatin analog with affinity for somatostatin receptors 2,4 and 5 is a potent inhibitor of human GH secretion. J Endocrinol Invest 27, 721-7.

[54] Reubi, J.C., Eisenwiener, K.P., Rink, H., Waser, B. and Macke, H.R. (2002) A new peptidic somatostatin agonist with high affinity to all five somatostatin receptors. Eur J Pharmacol 456, 45-9.

[55] Patel, R.C., Kumar, U., Lamb, D.C., Eid, J.S., Rocheville, M., Grant, M., Rani, A., Hazlett, T., Patel, S.C., Gratton, E. and Patel, Y.C. (2002) Ligand binding to somatostatin receptors induces receptor-specific oligomer formation in live cells. Proc Natl Acad Sci U S A 99, 3294-9.

[56] Rocheville, M., Lange, D.C., Kumar, U., Sasi, R., Patel, R.C. and Patel, Y.C. (2000) Subtypes of the somatostatin receptor assemble as functional homo- and heterodimers. J Biol Chem 275, 7862-9.

[57] Armstrong, D. and Strange, P.G. (2001) Dopamine D2 receptor dimer formation: evidence from ligand binding. J Biol Chem 276, 22621-9.

[58] Ng, G.Y., O'Dowd, B.F., Lee, S.P., Chung, H.T., Brann, M.R., Seeman, P. and George, S.R. (1996) Dopamine D2 receptor dimers and receptor-blocking peptides. Biochem Biophys Res Commun 227, 200-4.

[59] Grant, M., Patel, R.C. and Kumar, U. (2004) The role of subtype-specific ligand binding and the $\mathrm{C}$-tail domain in dimer formation of human somatostatin receptors. $\mathrm{J}$ Biol Chem 279, 38636-43.

[60] AbdAlla, S., Lother, H., el Massiery, A. and Quitterer, U. (2001) Increased AT(1) receptor heterodimers in preeclampsia mediate enhanced angiotensin II responsiveness. Nat Med 7, 1003-9.

[61] McGraw, D.W., Mihlbachler, K.A., Schwarb, M.R., Rahman, F.F., Small, K.M., Almoosa, K.F. and Liggett, S.B. (2006) Airway smooth muscle prostaglandin-EP1 
receptors directly modulate beta2-adrenergic receptors within a unique heterodimeric complex. J Clin Invest 116, 1400-9.

[62] Bhushan, R.G., Sharma, S.K., Xie, Z., Daniels, D.J. and Portoghese, P.S. (2004) A bivalent ligand $(\mathrm{KDN}-21)$ reveals spinal delta and kappa opioid receptors are organized as heterodimers that give rise to delta(1) and kappa(2) phenotypes. Selective targeting of delta-kappa heterodimers. J Med Chem 47, 2969-72.

[63] Baragli, A., Alturaihi, H., Watt, H.L., Abdallah, A. and Kumar, U. (2007) Heterooligomerization of human dopamine receptor 2 and somatostatin receptor $2 \mathrm{Co}-$ immunoprecipitation and fluorescence resonance energy transfer analysis. Cell Signal 19, 2304-16.

[64] Pfeiffer, M., Koch, T., Schroder, H., Klutzny, M., Kirscht, S., Kreienkamp, H.J., Hollt, V. and Schulz, S. (2001) Homo- and heterodimerization of somatostatin receptor subtypes. Inactivation of sst(3) receptor function by heterodimerization with $\operatorname{sst}(2 \mathrm{~A})$. J Biol Chem 276, 14027-36.

[65] Zatelli, M.C., Piccin, D., Tagliati, F., Bottoni, A., Ambrosio, M.R., Margutti, A., Scanarini, M., Bondanelli, M., Culler, M.D. and degli Uberti, E.C. (2005) Dopamine receptor subtype 2 and somatostatin receptor subtype 5 expression influences somatostatin analogs effects on human somatotroph pituitary adenomas in vitro. $\mathrm{J}$ Mol Endocrinol 35, 333-41.

[66] Ren, S.G., Kim, S., Taylor, J., Dong, J., Moreau, J.P., Culler, M.D. and Melmed, S. (2003) Suppression of rat and human growth hormone and prolactin secretion by a novel somatostatin/dopaminergic chimeric ligand. J Clin Endocrinol Metab 88, 541421.

[67] Gruszka, A., Kunert-Radek, J., Radek, A., Pisarek, H., Taylor, J., Dong, J.Z., Culler, M.D. and Pawlikowski, M. (2006) The effect of selective sst1, sst2, sst5 somatostatin receptors agonists, a somatostatin/dopamine (SST/DA) chimera and bromocriptine on the "clinically non-functioning" pituitary adenomas in vitro. Life Sci 78, 689-93.

[68] Ferone, D., Arvigo, M., Semino, C., Jaquet, P., Saveanu, A., Taylor, J.E., Moreau, J.P., Culler, M.D., Albertelli, M., Minuto, F. and Barreca, A. (2005) Somatostatin and dopamine receptor expression in lung carcinoma cells and effects of chimeric somatostatin-dopamine molecules on cell proliferation. Am J Physiol Endocrinol Metab 289, E1044-50.

[69] Hofland, L.J., van der Hoek, J., van Koetsveld, P.M., de Herder, W.W., Waaijers, M., Sprij-Mooij, D., Bruns, C., Weckbecker, G., Feelders, R., van der Lely, A.J., Beckers, A. and Lamberts, S.W. (2004) The novel somatostatin analog SOM230 is a potent inhibitor of hormone release by growth hormone- and prolactin-secreting pituitary adenomas in vitro. J Clin Endocrinol Metab 89, 1577-85.

[70] Hofland, L.J., van der Hoek, J., Feelders, R., van Aken, M.O., van Koetsveld, P.M., Waaijers, M., Sprij-Mooij, D., Bruns, C., Weckbecker, G., de Herder, W.W., Beckers, A. and Lamberts, S.W. (2005) The multi-ligand somatostatin analogue SOM230 inhibits ACTH secretion by cultured human corticotroph adenomas via somatostatin receptor type 5. Eur J Endocrinol 152, 645-54.

[71] Resmini, E., Dadati, P., Ravetti, J.L., Zona, G., Spaziante, R., Saveanu, A., Jaquet, P., Culler, M.D., Bianchi, F., Rebora, A., Minuto, F. and Ferone, D. (2007) Rapid pituitary tumor shrinkage with dissociation between antiproliferative and antisecretory effects of a long-acting octreotide in an acromegalic patient. J Clin Endocrinol Metab 92, 1592-9.

[72] Casnici, C., Lattuada, D., Crotta, K., Mastrotto, C., Franco, P., Culler, M.D. and Marelli, O. (2006) Effects of chimeric somatostatin-dopamine molecules on human peripheral blood lymphocytes activation. J Neuroimmunol 179, 9-17. 
[73] Jaquet, P., Gunz, G., Saveanu, A., Barlier, A., Dufour, H., Taylor, J., Dong, J., Kim, S., Moreau, J.P. and Culler, M.D. (2005) BIM-23A760, a chimeric molecule directed towards somatostatin and dopamine receptors, vs universal somatostatin receptors ligands in GH-secreting pituitary adenomas partial responders to octreotide. J Endocrinol Invest 28, 21-7.

[74] Fusco, A., Gunz, G., Jaquet, P., Culler, M.D., Barlier, A. and Saveanu, A. (2007) Somatostatinergic Ligands in Dopamine Sensitive or Resistant Prolactinomas. In: The Endocrine Society's 89th Annual Meeting, pp. 298 (P1-555), Toronto.

[75] Florio, T., Barbieri, F., Spaziante, R., Zona, G., Hofland, L.J., van Koetsveld, P.M., Feelders, R.A., and Stalla, G.K., Theodoropoulou, M., Culler, M.D., Moreau, J.P., Saveanu, A., Gunz, G. and Jaquet, P. (2006) Dopamine/Somatostatin chimeric molecules inhibit proliferation of human clinically nonfunctioning adenoma cells in vitro: a multicenter study. In: 12th Meeting of the European NeuroEndocrine Association, pp. 30 (S9.45), Athens.

[76] O'Toole, D., Saveanu, A., Couvelard, A., Gunz, G., Enjalbert, A., Jaquet, P., Ruszniewski, P. and Barlier, A. (2006) The analysis of quantitative expression of somatostatin and dopamine receptors in gastro-entero-pancreatic tumours opens new therapeutic strategies. Eur J Endocrinol 155, 849-57.

[77] Hofland, L.J., Lamberts, S.W., van Hagen, P.M., Reubi, J.C., Schaeffer, J., Waaijers, M., van Koetsveld, P.M., Srinivasan, A., Krenning, E.P. and Breeman, W.A. (2003) Crucial role for somatostatin receptor subtype 2 in determining the uptake of [111InDTPA-D-Phe1]octreotide in somatostatin receptor-positive organs. J Nucl Med 44, 1315-21.

[78] Pfeiffer, M., Koch, T., Schroder, H., Laugsch, M., Hollt, V. and Schulz, S. (2002) Heterodimerization of somatostatin and opioid receptors cross-modulates phosphorylation, internalization, and desensitization. J Biol Chem 277, 19762-72.

[79] Brink, C.B., Harvey, B.H., Bodenstein, J., Venter, D.P. and Oliver, D.W. (2004) Recent advances in drug action and therapeutics: relevance of novel concepts in Gprotein-coupled receptor and signal transduction pharmacology. Br J Clin Pharmacol 57, 373-87.

[80] Maudsley, S., Martin, B. and Luttrell, L.M. (2005) The origins of diversity and specificity in g protein-coupled receptor signaling. J Pharmacol Exp Ther 314, 485-94.

[81] Ostrom, R.S., Post, S.R. and Insel, P.A. (2000) Stoichiometry and compartmentation in $\mathrm{G}$ protein-coupled receptor signaling: implications for therapeutic interventions involving G(s). J Pharmacol Exp Ther 294, 407-12.

[82] Sharif, N., Gendron, L., Wowchuk, J., Sarret, P., Mazella, J., Beaudet, A. and Stroh, T. (2007) Coexpression of somatostatin receptor subtype 5 affects internalization and trafficking of somatostatin receptor subtype 2. Endocrinology 148, 2095-105.

[83] Kenakin, T. (2002) Efficacy at G-protein-coupled receptors. Nat Rev Drug Discov 1, 103-10.

[84] Canals, M., Marcellino, D., Fanelli, F., Ciruela, F., de Benedetti, P., Goldberg, S.R., Neve, K., Fuxe, K., Agnati, L.F., Woods, A.S., Ferre, S., Lluis, C., Bouvier, M. and Franco, R. (2003) Adenosine A2A-dopamine D2 receptor-receptor heteromerization: qualitative and quantitative assessment by fluorescence and bioluminescence energy transfer. J Biol Chem 278, 46741-9.

[85] Hakak, Y., Shrestha, D., Goegel, M.C., Behan, D.P. and Chalmers, D.T. (2003) Global analysis of G-protein-coupled receptor signaling in human tissues. FEBS Lett 550, 117.

[86] Watt, H.L. and Kumar, U. (2006) Colocalization of somatostatin receptors and epidermal growth factor receptors in breast cancer cells. Cancer Cell Int 6, 5. 
[87] Kenakin, T. and Onaran, O. (2002) The ligand paradox between affinity and efficacy: can you be there and not make a difference? Trends Pharmacol Sci 23, 275-80.

[88] Marbach, P., Briner, U., Lemaire, M., Schweitzer, A. and Terasaki, T. (1993) From somatostatin to Sandostatin: pharmacodynamics and pharmacokinetics. Digestion 54 Suppl 1, 9-13.

[89] van der Hoek, J., de Herder, W.W., Feelders, R.A., van der Lely, A.J., Uitterlinden, P., Boerlin, V., Bruns, C., Poon, K.W., Lewis, I., Weckbecker, G., Krahnke, T., Hofland, L.J. and Lamberts, S.W. (2004) A single-dose comparison of the acute effects between the new somatostatin analog SOM230 and octreotide in acromegalic patients. J Clin Endocrinol Metab 89, 638-45.

[90] Culler, M.D. (2007) Dopamine and somatostatine chimeras. In: 9th European Congress of Endocrinology, pp. Ipsen Satellite Symposium, Budapest. 
Table 1:

Modifications induced by D2DR heterodimerization with sst5 (left column) and sst2 (right column) in cotransfected heterologous cells (CHO and/or HEK293).

\begin{tabular}{|l|l|l|}
\hline & Sst5-D2DR & Sst2-D2DR \\
\hline $\begin{array}{l}\text { Ligand induced } \\
\text { heterodimerization }\end{array}$ & $\begin{array}{l}\text { YES } \\
\text { Sst5 agonist }+ \text { D2DR agonist } \geq \\
\geq \text { sst5 agonist } \geq \\
\geq \text { D2DR agonist }\end{array}$ & $\begin{array}{l}\text { YES } \\
\text { Sst2 agonist }+ \text { D2DR agonist }= \\
=\text { D2DR agonist }> \\
>\text { Sst2 agonist }\end{array}$ \\
\hline Ligand binding & $\begin{array}{l}\text { D2DR agonist } \uparrow \\
\text { Sst5 agonist } \uparrow \uparrow\end{array}$ & $\begin{array}{l}\text { D2DR agonist } \uparrow \\
\text { Sst2 agonist }=(\text { total number of } \\
\text { binding sites } \uparrow \text { ) }\end{array}$ \\
\hline $\begin{array}{l}\text { Activation of } \\
\text { transduction } \\
\text { pathway (cAMP) }\end{array}$ & $\begin{array}{l}\text { Sst5+D2DR agonist }> \\
>\text { sst5 agonist }= \\
=\text { D2DR agonist }\end{array}$ & $\begin{array}{l}\text { Sst2+D2DR agonist }> \\
>\text { D2DR agonist (EC50) }\end{array}$ \\
\hline $\begin{array}{l}\text { Receptor } \\
\text { internalization }\end{array}$ & ND & Sst2 agonist $\neq$ \\
\hline
\end{tabular}

Data summarized from Rocheville et al. [51] and Baragli et al. [63]

$\uparrow$ increased, $\uparrow \uparrow$ sharply increased, $=$ similar,

$\neq$ modified (decreased as compared to sst 2 expressing only cells, but earlier action )

In experiments: Sst5 agonist $=$ somatostatin 14; Sst2 agonist $=$ somatostatine 14; D2DR agonist $=$ dopamine or quinpirole. $\mathrm{ND}=$ not done 
Table 2 :

Human sst and D2DR binding affinities of chimeric dopastatin drugs as compared to native somatostatin, commonly used somatostatin drugs and multi-sst ligands (nmol/L).

\begin{tabular}{|c|c|c|c|c|c|c|}
\hline Compound & sst 1 & sst2 & sst3 & sst4 & sst5 & D2DR \\
\hline SRIF $14^{4}$ & 2.3 & 0.2 & 1.4 & 1.8 & 1.4 & ND \\
\hline \multicolumn{7}{|c|}{ Sst2 preferential agonists } \\
\hline Octreotide $^{1}$ & 1140 & 0.6 & 34 & 7030 & 7.0 & ND \\
\hline Lanreotide $^{1}$ & 2129 & 0.7 & 98 & 1826 & 12.7 & ND \\
\hline \multicolumn{7}{|c|}{ Multi-sst ligands } \\
\hline BIM-23244 & $>1000$ & 0.3 & 133 & $>1000$ & 0.7 & ND \\
\hline SOM-230 2 & 9.3 & 1.0 & 1.5 & $>100$ & 0.2 & ND \\
\hline BIM-23A $779^{3}$ & 2.5 & 0.3 & 0.6 & 20 & 0.6 & ND \\
\hline \multicolumn{7}{|l|}{ Dopastatins } \\
\hline BIM-23A387 & 293 & 0.2 & 77 & $>1000$ & 26 & 22 \\
\hline BIM-23A758 & 468 & 0.1 & 324 & $>1000$ & 27 & 13 \\
\hline BIM-23760, & 622 & 0.03 & 160 & $>1000$ & 3.1 & 15 \\
\hline BIM-23761 & 462 & 0.06 & 52 & $>1000$ & 3.7 & 27 \\
\hline BIM-23765 & $>1000$ & 0.2 & 76 & $>1000$ & 7 & 9 \\
\hline
\end{tabular}

Data for SOM-230 are from Weckbecker et al. [39]. The values for the BIM compounds are from Ipsen as previously published 1 [40], 2 [52] and 4 [15]. ND=not done. 